\title{
RONSARD AND YEATS: AN EXERCISE IN INTERTEXTUALITY
}

\author{
Sigrid Renaux ${ }^{*}$
}

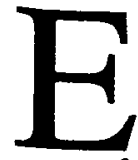

ven if W.B. Yeats's poem "When You Are Old" ${ }^{1}$ is perfectly understandable and universal in its appeal without our knowing its literary source - Pierre Ronsard's sonnet "Quand Vous Serez Bien Vieille $^{\prime 2}$ - nevertheless it is worth-while to investigate the influence which Ronsard's text has exerted on Yeats's, by way of an intertextual approach of both poems, in order to enrich our aesthetic perception of them through the illumination which one text provides for the other. As J.T. Shaw comments, in his discussion of literary indebtedness,

some scholars and critics (...) seem to feel that to suggest an author's literary debts diminishes his originality. But originality shoud not be understood in terms of innovation. (...) What genuinely moves the reader aesthetically and produces an independent artistic effect has aristic originality, whatever its debts. The original author is (...) the

\footnotetext{
-Universidade Federal do Paranà
}

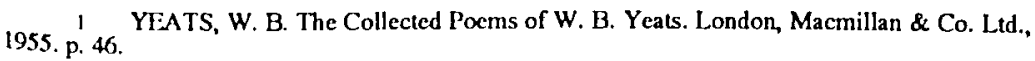

2 LAGARDE, A. \& MICHARD, L. XVIe. Siècle. Paris, Bordas, 1965. p. 145. 
one who succeeds in making all his own, in subordinating what he takes from others to the new complex of his own artistic work ${ }^{3}$

Most editions of Yeats's poem mention his debt to Ronsard's Sonnets pour Hélène $h$, xliii, calling it Yeats's point of departure, his adaptation or free translation of the original, but only an approach in depth can bring out the parallelisms of contrast and similarity which pervade both texts, in terms of thematic patterns, links, analogies, fictional worlds, imagery, all of them either veiled or oven, and which exactly point to Yeats's artistic originality.

On the other hand, if one considers that Yeats wrote his poem when he was twenty-seven years old and at the start of his career, while Ronsard, already fifty-four and starting to decline from the height of his fame as "Prince des Poètes" when he wrote his famous collection of sonnets, it immediately strikes us that Ronsard's influence cannot be underestimated, be it in style, images, themes, characters, as well as in thought and "Weltanschauung". A quick glance into Ronsard's and Yeats's literary traditions will confirm this influence, and will sharpen the intertextual approach that follows, by bringing both texts into the perspective of their time and place.

Ronsard (1524-1585) was the greatest poet of the Pléiade, a group of seven poets who "represent the most spectacular triumph of French poetry in the Renaissance", imbedded as their art was with "mythology and nature":

rivers, woods, roses, dew and nymphs are everywhere in their verses, forming the natural setting for the serious themes of happiness, love, and death. Even more, "some of their poetry is of a springlike tendemess and hopefulness, despite their awareness of life's uncertainties and the destruction of sentiment and beauty that the passing of time brings. ${ }^{4}$

If great literary symbols and themes are almost archetypical, one can see a first parallelism established between the XVIth century literary tradition of the Pléiade and Yeats's conception of poetry: his concern with Irish nature and mythology, and his use of images and symbols in his youth poems borrowed from Gaelic tradition and literature - the rose, the hazel-nut tree,

3 SHAW, J. T. "Literary Indebtedness and Comparative Litexary Studies". In: Comparative Literature Method and Perspective. Ed. Stallknecht and Frenz. Carbondale, Southem Illinois University Press, 1973. p. 85-6.

4 PREMINGER, A. ed. Ptinceton Encyclopedia of Poetry and Poetics. New Jersey, Princeton University Press, 1974. p. 292 
Cuchulain and Deirdre - besides the recurrent images of the tree, the tower, birds, the sea, stars, wells and masks, often used in a personal and many times secret way, and based on reality. Thus, although Yeats's acknowledged masters are specifically Spenser, Blake, Shelley, the Pre-Raphaelites as well as the French symbolists, we can establish a distant horizon of influence between Yeats and the Pléiade, which will now be qualified in relation to Ronsard"s background concerning the Sonnets pour Hélène.

As the most celebrated poet in Europe, Ronsard immortallized, in his Sonnets pour Hélène (1578), the figure of Hélène de Surgères, maid of honor of Catherine de Médicis, who was remarkable not only for her "esprit" and virtue but also by her beauty. The queen had invited Ronsard to "celebrate" her in his verse, because Hélène was inconsolable due to the death of her fiancé in civil war. Ronsard not only sang her under the orders of the queen but, in spite of their difference in age and her reserve, he came to love her sincerely and expressed his "autumnal love" in sonnets of stirring melancholy and sensitive lyricism, and which are among his most perfect works. ${ }^{5}$

Yeats, in turn, as a young poet of twenty-four, met the beautiful and fiery actress and Irish nationalist Maud Gonne, and fell completely in love with her. Similarly to Ronsard's Hélène, she refused any thing more than his friendship and becomes - in spite or because of this refusal - the inspirator of a long train of love poems, starting with The Rose poems (1893). In this volume one can find, besides poems dealing with the occult and with Ireland, poems such as "When You Are Old", "The Pity of Love", "The Sorrow of Love" as well as the specific "Rose" poems which are, according to A.G. Stock, "at once a lover's homage to his mistress and a condensation of Yeats's philosophy, for to him all worship was one worship and all beauty the embodiment of a single idea" ${ }^{6}$

Let us now juxtapose both poems, in order to discuss Yeats's assimilation and transformation of Ronsard's sonnet, by way of an intertextual exercise:

\section{QUAND VOUS SEREZ BIEN VIEILLE...}

6 STOCK, A. G. W. B. YEATS: His Poetry and Thought Cambrige, Cambrige University E'tess, 1964. p. 45. 
Quand vous serez bien vieille, au soir, à la chandelle, Assise auprès du feu, dévidant et filant, Direz, ctantant mes vers, en vous émerveillant:

"Ronsard me célébrait du temps que j"ètais belle"!

Lors, vous n'aurez servante oyant telle nouvelle, Déjà sous le labeur à demi sommeillant, Qui au bruit de Ronsard ne s'aille réveillant.

Bénissant votre nom de louange immortelle.

Je serai sous la terre, el, fantòme sans os, Par les ombres myrteux je prendai mon repos:

Vous serez au foyer une vieille accroupie,

Regrettant mon amour et votre fier dédain. Vivez, si m'en croyez, $n$ 'attendez à demain, Cueillez dès aujourd hui les roses de la vic.

Pierre Ronsard Sonnets Pour Hélène, Il, xliii

\section{WHEN YOU ARE OLD}

When you are old and gray and full of sleep. And nodding by the fire, take down this book, And slowly read, and dream of the soft look Your cyes had once, and of their shadows deep;

How many loved your moments of glad grace, And loved your beauty with love false or true; But one man loved the pilgrim soul in you, And loved the sorrows of your changing face.

And bending down beside the glowing bars Murmur, a little sadly, how love fled And paced upon the mountains overhead And hid his face amid a crowd of stars.

William Butler Yeats

The Rose 
Examining both texts according to Z. Ben-Porat's theoretical and nomenclature, ${ }^{7}$ the following constant features of a borrowing are present herc: the independent existence of both texts; the presence of several signals in the alluding text; the presence of elements in both texts which can be linked together in intertextual patterns of an unpredictable nature; the process of actualization which reflects the effort to reconstruct a fuller text.

The form of the borrowing is overt, due to the specific mentioning of "When You Are Old" in the title, which makes for a strong marker, since the marked text "Quand Vous Serez Bien Vieille..." is well-known.

As to the stages of the process, if the first part of the process of actualizing the allusion is relatively easy - the isolation of the signals, and the identification and recovery of the referent text, due to the fact that we are dealing with initially related texts, the two following steps - the modification of the initial local interpretation of the signal and the activation of the evoked text as a whole, demand a deeper reading of both poems. This will be done by segmenting the texts into units of reading or "lexias" 8 to better appreciate the intertextual relationships established between the signals of the alluding and of the evoked text:

1. Quand vous serez bien vicille, au soir, à la chandelle,

2. Assise auprés du feu, dévidant et filant,

11. Vous serez au foyer une vieille accroupie.

In Ronsard, lines 1 and 2 are repeated, in a condensed manner, in line 11, the parallelism thus foregrounding the motif of the beloved seen as an old woman. This same device is also apparent in Yeats, for

1. When you are old and gray and full of sleep,

2. And nodding by the firc,

are also paralleled in a summarized manner in line

9: And bending down beside the glowing bars,

7 BEN-PORAT, 7.. "The Poctics of Litcrary Allusion". In: PTL: A Journal for Descriptive Poeties and Theory of Literature I (105-128). North-Holland Publishing Co., 1976.

8 BARTHFS, R. "Textual Analysis of Poe's 'Valdmar'. In: YOUNG, R. ed. Untying the Text. Boston, Routledge \& Kegan I'aul, 1981. p. 136. 
thus confirming his similarity of concern with Ronsard in highlighting their vision of their beloved women in old age.

In this way, the motif of both addressees, envisaged as old ladies, one spinning, the other nodding beside the fire, at night, is set right at the beginning of both texts and then retaken almost at the end, the repetition reminding us of its importance as the starting point for both poets' argument, for the addressees" old age already implies in their loss of beauty.

The fact that Yeats did not include "reeling and spinning" in his poem, substituting it by "nodding", also makes sense, if one considers that this activity would be more pertinent in a XVIth century context than in Yeats's time, besides the fact that Maud Gonne could hardly be imagined spinning by the fireside.

The fictional worlds of both poems also start out as being the same, for the setting, in Ronsard, foregrounds the contrast between the darkness of evening with the candlelight and the hearth which illuminate the addressce, and the same image of the hearth is present in Yeats's poem. The correspondence between the images is more striking, when they become juxtaposed: "à la chandelle", "auprès du feu", "au foyer" with "by the fire" and "beside the glowing bars". The omission of candlelight in Yeats can again be justified, for if in the XVIth century candles were the lighting of rich families, this would no longer be the case in Yeats's time. But all these images share a common denominator: fire, symbolic of light, life, imagination, forbidden passions. ${ }^{9}$ The hearth or fireplace is also symbolic of humane warmth, as the centre of home; the candle, in turn, besides its specific symbolism of creating a romantic mood, is often used to represent the stars (an image that will be retaken at the end of Yeats's poem), as well as being symbolic of the external soul and of the life of the individual, in opposition of cosmic and universal life (an idea that will also be discussed further on).

Thus, "fire" in both evoked and alluding text makes for a very strong marker, not only in visual terms, by illuminating the visible if hypothetical setting of both poems, but also by endowing the two old ladies with the possibility of dreaming of their past beauty and past loves, through its symbolic charge.

One could still add that the picture of the "vieille accroupie" in Ronsard is much stronger and cruder than Yeats's image of the addressee "bending down beside the glowing bars", which suggests a more voluntary

9 All references to symbols are taken from DE VRIES, A. Dictionary of Symbols and Imagety. Ansterdam, North-Holland Publishing Company, 1974. 
action than "accroupie". This toning down, in Yeats, of the results of old age, could be attributed to the fact that he would be sparing his beloved Maud of such a cruel sight while, in Ronsard, the strong "accroupic" could be a further device to make Hélène change her mind and listen to his appeal to "gather the roses of life today".

Our next "lexia" or textual signifier would be, in Ronsard, lines

3. Direz, chantant mes vers, en vous émerveillant":

4. "Ronsard me célébrait du temps que j'ètais belle!

These lines bring sound and song to the sonnet, in its metalinguistic reference to the text itself, and in its foregrounding the beauty of the beloved lady, when young, and immortalized in Ronsard's verse. The nuance of admiration and astonishement implied in "emerveillant" (from the Latin mirabilia $=$ merveilles) adds a dreamlike tone to the addressee's words in line 4, highlighting not only her beauty but also the fact that Europe's greatest poet had sung her.

In Yeats, the metalinguistic device is kept, but with a different resonance, for the addressee will read the book of poems dedicated to her, but will only dream of her past beauty, instead of singing the poet's verse. Nonetheless, even if the actions of speaking and singing in Ronsard are transformed into reading and dreaming in Yeats, both texts are again brought together, through the signal "dreaming" sends us back to "emerveillant" and "marvel" as synonymous with dream. Even more, the dream-like state so explicit in Yeats's old lady will become explicit in Ronsard in the second quartet, but in relation to the lady's servant who, at the name of Ronsard, would rise "réveillant" from her half-sleep. The sound similarity between "emerveillant/réveillant" confirms their similarity in meaning while in Yeats' $s$ "read, and dream", assonance contributes to the metonymic relationship established between both actions, thus foregrounding the dream-like quality which pervades both poems once more.

Looking more closely at Yeats's lines,

2. (...) take down this book,

3. And slowly read, and dream of the soft look

4. Your eyes had once, and of their shadows decp:

one also realizes that, in terms of the addressor, Yeats almost annuls himself 
as a poet speaking to his beloved, in contrast to Ronsard's presence in the poem in the words of his lady, as seen in line 4 . Yeats only refers to "this book", which we surmise to be of his poems. Both stances again make sense, if one remembers that Ronsard, in asserting his power as a poet was writing in his tradition and thus, when he refers to himself in the first person, in the two tercets, there is no doubt about his identity, for his name pervades all four stanzas, besides the indirect reference to himself in line 3 , when his beloved will be "chantant mes vers".

This same attitude becomes foregrounded again in the second quarteh, when Ronsard continues the argument of visualizing his beloved in old age:

5. Lors, vous $n^{\circ}$ aurez servante oyant telle nouvelle,

6. Déjà sous le labeur à demi sommeillant,

7. Qui au bruit de Ronsard ne s'aille reveillant,

8. Bènissant votre nom de louange immortelle.

The stress seems to be much more on the image of the half-awakened servant, who would dreamingly rise at the sound of his name as he blesses his beloved lady's beauty in "immortal praise", than in the fact that he is foreshadowing her lonesomeness in old age, without even a servant to be listening to her pronouncing Ronsard's name. But an interesting device occurs here, in relation to the servant being "à demi sommeillant", for the idea of the servant being sleepy or falling asleep has been transferred by Yeats to the first line of his poem, in relation to his lady being "full of sleep and nodding" with its further suggestion of being tired because it is late but also because she is old and probably near her own death. Thus a more complicated intertextual relationship is established between these "lexias", in which "full of sleep/And nodding by the fire" seem to foreshadow what will happen in Ronsard's second quartet, when actually it is Ronsard's text that is being evoked, so one could say that the reverberations of his lines are felt all over Yeats's poem.

Following the same attitude he has taken in the first stanza, Yeats continues to put all the emphasis on his beloved person, instead of simultaneously on himself, as Ronsard does. If in the first stanza he was already expanding the concept of the lady's beauty in relation to "belle" in Ronsard - the only word which actually describes Hélène's physical beauty - by mentioning the "soft look" of her eyes, and "their shadows deep", a metonymical process is now established in Yeats 's poem which is not extant 
in Ronsard: the association of her beauty with the love she has inspired in other men, from lines 5 to 8 :

5. How many loved your moments of glad grace,

6. And loved your beauty with love false or true;

7. But one man loved the pilgrim soul in you,

8. And loved the sorrows of your changing face.

This de-emphasizing of the poet's role, already begun in the first stanza, is here intensified by his concentrating on the most important paradigm pervading his poem - love - repeated as a verb in each of the four lines of the second stanza and once as a noun; and recovered again in the last stanza, this time as personification. This is actually the great difference between both texts, for Yeats continues the metonymical process by expanding on the lady's "moments of glad grace", with its suggestions of being pleasing, charming and attractive, as well as of willingness and favour towards the men who loved her beauty, "with love false or true". The addresser himself has now become the "one man" who loved her "pilgrim soul" and the "sorrows" of her "changing face", thus isolating himself from the many who loved only her physical beauty and moments of joy. His love is Platonic and disinterested, and sensitive to her "pilgrim soul - with its implication of human soul, love, and transcendence - as well as concerned with the "sorrows" of her face which would gradually look older, or would express grief. Ronsard, as seen, does not develop the theme of the lady's beauty, but prefers to concentrate in the second quartet to point out that the lady's consolation in saying that Ronsard sang her when she was young and beautiful is of no avail to her, for there would be no servant by her to listen to it and marvel at it. The idea of loneliness, though, pervades both poems, and will be retaken in Ronsard's first tercet, when he refers to himself as

\section{Je serai sous la terre, $c$, fantôme sans os, \\ 10. Par les ombres myrtcux je prendrai mon repos:}

Thus, in the same way that no servant would be near his beloved, when she is old, he would not be there either, as a boneless ghost among the dead, and would be in peace, in contrast to her being alive and regretful, as the next two lines will show. Yeats, once again, does not refer to his state after death, so emphasized by Ronsard, in this way further deflating his role in the poem, in contrast to Ronsard's dividing his role of hero in the poem 
with his heroine. Thus, the constant parallelism between both texts is toned down in Yeats, in relation to his function as a poet, which has to be intuited from "take down this book, and slowly read, and dream"; this would correspond in content to Ronsard's "chantant mes vers", as well as in relation to his role as lover, one among many, in contrast to Ronsard's dominating figure in the sonnet.

Nevertheless, this de-emphasizing leads us into a fictional world in Yeats's last stanza which can not only be juxtaposed to Ronsard's underworld setting but even reverse it. If Ronsard has become a boneless ghost amid the shades of the myrles - consecrated to Venus and haunted, according to Virgil, by people in love - in Yeats's last stanza, this underworld setting is transcontextualized into a metaphysical world, for Yeats's "lover" - the one man who loved the "pilgrim soul" in the lady - has become metaphorized into the very image of "love":

9. And bending down beside the glowing bars

10. Murmur, a little sadly, how love fled

11. And paced upon the mountains overhead

12. And his his face amid a crowd of stars.

But this personification of "love", which has fled to the mountains overhead - with its connotation of a realm of meditation, solitariness, freedom, peace, as well as symbolic of the world-axis and thus of contact between heaven and earth - this attributing "love" with human shape through "face" - and action - fleeing, pacing and hiding - prepares us for the great leap achieved at the end of the poem, when, in an ascending movement, "love" reaches the stars. In this way, Yeats moves from the circumscribed setting of the fireplace to the openness of the mountains and the cosmic dimension and universality implicit in the stars, while Ronsard remains with a descending movement from the "foyer" to the underworld setting where he has been taken, and where he rests among the myrtle shades - the loving poet among the shades of lovers. But we cannot forget that this descending movement in Ronsard is a device for convincing the lady to listen to his graceful appeal to enjoy life, as his two concluding lines will reveal, shortly.

Ronsard's next two lines, 11. "Vous serez au foyer une vieille accroupie," (already discussed above together with Yeats's line 9) and 12. "Regrettant mon amour et votre fier dédain," point out that "love" is mentioned only once in the sonnet, and set in contrast to the lady's cruel contempt. But both feelings are subordinate to her regretting not having 
accepted his love and also missing it - both meanings are implied in "regrettant" - and to also regretting her rejection of his love.

It becomes clear now, why Ronsard has taken such a contained attitude at this point in his sonnet, ending on this note of regret. It is because, besides the theme of immortality which a poet of his tradition would bestow upon his beloved by simply praising her beauty, he also introduces the Carpe Diem theme, again a common device in his time, when he invites Hélène to live and gather the roses of life from now on:

13. Vivez, si m'en croyez, n'attendez à demain;

14. Cueillez des aujourd hui les roses de la vic.

Love is of course implicit in this plea for life, as well as explicit through the symbolism of the rose, as the hidden centre of love, but it does not have the pervasive function it has in Yeats who, young and idealistic, not only develops the theme of love in the second stanza, but gives it a cosmic dimension when he describes its leaving this human world and hiding its face - in sadness or tiredness? - amid a crowd of stars, with their symbolism of heavenly light, immortality and the soul. In Yeats, the theme of immortality through the poet's praise of a lady's beauty becomes restricted to the addressce's dreaming of her past beauty and of the love she has inspired in other men and the Carpe Diem motif is completely ignored, having been substituted by the slight regret - "murmur, a little sadly" - of realizing that, with the loss of beauty, love has also fled. This would also make the reading of the book of poems more poignant, by reminding her of what is gone. Thus, the threat of old age and the regret of realizing the flight of love, common to both poems, acquire different nuances in Ronsard and in Yeats, which at the end take us to different conceptions of life - one Epicurean or Horatian, the other more stoic and transcendental.

It becomes clear now, why both poets return to the image of the bending woman at the end of their poems - to make the plea for Carpe Diem more pressing, and to stress the loss of love. Two opposing views, but brought together again by the discretion art and delicateness that pervades both poems, by the scrupulous art and the harmony of composition and movement which is behind every stanza.

In this way, by providing us with the recollection of the original form of the evoked text through the signals interspersed in his poem, Yeats has "activated" Ronsard's poem in several ways:

- Establishing an analogy between both texts and thus abolishing the 
distance in time which separates both poems, for the loss of beauty and the flight of love are timeless and universal.

- Creating a fictional world which parallels Ronsard's at the start, but which then opens up to the infinite, thus making the descending movement in Ronsard's poem more contained, even if poetically the two images can be brought together by the visualising of the shiny leaves and white flowers of the myrtle and the shiny whiteness of the crowd of stars.

- Establishing dialectical bonds between words and images in both poems, thus highlighting the essential concern of both poets of conveying beauty to us, through their common experience of the rejection of their love by a beautiful woman, and which each one has translated creatively and masterfully into words.

\section{RESUMO}

Este trabalho discute as relaçōes intertextuais que podem ser estabelecidas entre os poemas When You Are Old (1892), de W.B. Yeats, e Quand Vous Serez Bien Vieille (1578), de Pierre Ransard. Através da segmentação de ambos os textos em lexias, mostramos como os paralelismos de similaridade ede contraste a nivel temático, ficcional, imagético e da própria palavra, enfatizam a ativação que Yeats provocou no soneto de Ronsard e simultaneamente a criatividade de Yeats em subordinar esta fonte literária à sua própria capacidade antistica, desta maneira enriquecendo nossa percepção estética de ambos os poemas.

\section{BIBLIOGRAPHICAL REFERENCES}

BARTHES, R. "Textual Analysis on Poe's Valdemar". In: Young, R. ed. Untying the Text. Boston, Routledge \& K. Paul, 1981.

BEN-PORAT, Z. "The Poetics of Literary Allusion". In: PTL: A Joumal for Descriptive Poetics and Theory of Literature I(105-128). North-Holland Publishing Co., 1976.

DE VRIES. A. Dictionary of Symbols and Imagery. Amsterdam, Nonh-Holland Publishing Co., 1974.

LAGARDE, A. \& Michard, L. XVle. Siècle. Paris, Bordas, 1965.

PREMINGER A. ed. Princeton Encyclopedia of Poetry and Poetics. New Jersey, Princeton University Press, 1974.

SHAW, J. T. "Literary Indebtedness and Comparative Literary Studies". In: Comparative 
Literature. Method and Perspective. Ed. Stallknecht and Frenz. Carbondale, Southem Illinois University Press, 1973.

STOCK, A. G. W. B. Yeats: His Poetry and Thought. Cambridge, the University Press, 1964. YEATS. W. B. The Collected Poems of W. B. Yeats. London, Macmillan \& Co., 1955. 